\title{
Analisis Kemampuan Pemahaman Relasional Matematis : Dampak Strategi Pembelajaran Index Card Match
}

\author{
Fitri Wulandari ${ }^{*}$, Rosida Rakhmawati ${ }^{2}$ \\ ${ }^{1}$ Universitas Islam Negeri Raden Intan Lampung. Jalan Endro Suratmin, Sukarame, Bandar \\ Lampung 35133, Indonesia. \\ ${ }^{2}$ Coventry University, Priory St, Coventry CV1 5FB, United Kingdom \\ * Corresponding Author. E-mail: wulandarifitri0901@gmail.com
}

\begin{abstract}
Abstrak
Penelitian ini bertujuan untuk mengetahui (1) perbedaan kemampuan pemahaman relasional matematika peserta didik yang memperoleh pembelajaran dengan strategi pembelajaran Index Card Match dengan peserta didik yang memperoleh pembelajaran konvensional, (2) perbedaan kemampuan pemahaman relasional matematika peserta didik yang mempunyai minat belajar tinggi, sedang dan rendah, (3) interaksi strategi pembelajaran Index Card Match dan tingkat minat belajar peserta didik terhadap kemampuan pemahaman relasional matematika peserta didik. Metode yang dipakai dalam penelitian ini adalah eksperimen semu (Quasi Eksperimental Research). Pengujian hipotesis menggunakan anava dua jalan sel tak sama. Berdasarkan hasil penelitian dapat disimpulkan (1) Terdapat perbedaan kemampuan pemahaman relasional matematika peserta didik yang memperoleh pembelajaran dengan strategi pembelajaran Index Card Match dengan peserta didik yang memperoleh pembelajaran konvensional, (2) Terdapat perbedaan kemampuan pemahaman relasional matematika peserta didik yang mempunyai minat belajar tinggi, minat belajar sedang, dan minat belajar rendah, (3) Tidak terdapat interaksi antara strategi pembelajaran Index Card Match dan tingkat minat belajar peserta didik terhadap kemampuan pemahaman relasional matematika peserta didik.
\end{abstract}

Kata kunci: Kemampuan Pemahaman Relasional Matematis, Minat Belajar, Strategi Pembelajaran Index Card Match,

\begin{abstract}
This study aims to determine (1) differences in the ability of relational understanding of mathematics of students who get learning with Index Card Match learning strategies with students who obtain conventional learning, (2) differences in the ability of mathematical relational understanding of students who have high, medium and low, (3) interaction of Index Card Match learning strategies and the level of interest in learners 'learning on the students' mathematical relational understanding abilities. The method used in this study is a quasi-experimental (Quasi Experimental Research). Hypothesis testing using two-way cell anava is not the same. Based on the results of the study it can be concluded (1) There is a difference in the ability of mathematical relational understanding of students who get learning with Index Card Match learning strategies with students who obtain conventional learning, (2) There are differences in the ability of students to have a high learning interest interest in learning is moderate, and interest in learning is low, (3) There is no interaction between Index Card Match learning strategies and the level of interest in learners 'learning on students' mathematical relational understanding abilities.
\end{abstract}

Keywords: Index Card Match Learning Strategy, Learning Interest, Mathematical Relational Understanding Ability, 


\section{PENDAHULUAN}

Kesulitan peserta didik dalam belajar dapat dipengaruhi oleh berbagai faktor, salah satunya faktor psikologis. Salah satu faktor psikologis yang mempengaruhi proses belajar adalah minat belajar peserta didik. Minat pada dasarnya adalah penerimaan akan suatu hubungan antara diri sendiri dengan sesuatu di luar diri. Berdasarkan hasil penelitian psikologi menunjukkan bahwa kurangnya minat belajar dapat mengakibatkan kurangnya rasa ketertarikan pada suatu bidang tertentu, bahkan dapat melahirkan sikap penolakan kepada guru. Bila peserta didik sudah mempunyai minat untuk belajar matematika, maka dapat diasumsikan bahwa kesulitan peserta didik dalam belajar akan berkurang. Minat juga ialah satu dari faktor psikologis yang dapat mempengaruhi kuantitas serta kualitas belajar peserta didik. Karena itu, guru dituntut untuk membangkitkan minat siswa agar pelajaran yang diberikan mudah dipahami.

Berdasarkan hasil prasurvey peserta didik kelas VIII MTs Nurul Ulum diketahui bahwa peserta didik belum bisa mengaplikasikan konsep ataupun menggunakan, memanfaatkan dan memilih prosedur atau operasi aljabar, sehingga kemampuan pemahaman relasional peserta didik masih kurang, Peningkatan pemahaman relasional peserta didik dapat melewati beragam cara. Pertama, dengan strategi pembelajaran yang diterapkan yang dapat menunjang pembelajaran yang dinilai efektif. (Arrafat, 2014; Atikasari \& Woro Kurniasih, 2015; Hasanah, 2016; Saleh, 2013) Salah satu strategi pembelajaran yang dapat digunakan yaitu strategi index card match, yaitu strategi yang "mencari pasangan kartu" yang cukup menyenangkan digunakan untuk mengulangi materi pembelajaran yang telah diberikan sebelumnya, karena seharusnya dalam pembelajaran matematika peserta didik aktif dalam belajar, sehingga bisa terampil dalam mengembangkan kreatifitas dan bisa lebih memahami dalam menyelesaikan pemecahan masalah matematika. Kedua, guru diharapkan bisa menerapkan serta memilih strategi pembelajran yang bisa membuat peserta didik lebih aktif dalam pembelajran dan peserta didik bisa meningkatkan kemampuan dalam pemahaman pelajaran

Penelitian terdahulu telah banyak membahas mengenai penggunaan strategi pembelajaran Index Card Match (Arrafat, 2014; Darhim, 2013; Fauzi, 2017; Haryanto, 2011; Lusia, 2013; Rambe, 2018; Surur \& Urfi, 2017) serta kemampuan pemahaman relasional siswa (Uswatusolihah, 2015). Berdasarkan penelitian terdahulu keterbaruan penelitian ini terletak pada penggunaan strategi pembelajaran Index Card Match terhadap kemampuan pemahaman relasional siswa. Maka, tujuan penelitian ini adalah untuk mengetahui (1) perbedaan kemampuan pemahaman relasional matematika peserta didik yang memperoleh pembelajaran dengan strategi pembelajaran Index Card Match dengan peserta didik yang memperoleh pembelajaran konvensional, perbedaan kemampuan pemahaman relasional matematika peserta didik yang mempunyai minat belajar tinggi, sedang dan rendah, (3) interaksi strategi pembelajaran Index Card Match dan tingkat minat belajar peserta didik terhadap kemampuan pemahaman relasional matematika peserta didik.

\section{METODE PENELITIAN}

Metode yang digunakan dalam penelitiaan ini adalah eksperimen semu (Quasi Eksperimental Research). Sampel Dalam penelitian ini adalah siswa kelas 
VIII MTs Nurul Ulum yang terdiri atas 2 kelas ( eksperimen dan kontrol). Dalam pengambilan kelas eksperimen dan kelas kontrol, teknik yang digunakan adalah teknik acak kelas dengan teknik undian. Uji Komparasi Ganda Dengan Metode Scheffe'. Metode Scheffe' diakai sebagai tindak lanjut dari analisis variansi dua jalan. Metode Scheffe juga digunakan guna melihat perbedaan rata-rata tiap partner sel, baris, serta kolom dijadikan uji komparasi ganda.

\section{HASIL DAN PEMBAHASAN}

Hasil data minat belajar peserta didik didapat pada angket yang dikasih untuk peserta didik pada awal kegiatan belajar. Selanjutnya penggolongan data ke dalam 3 kriteria ialah tinggi, sedang, serta rendah. Peserta didik dengan skor $\geq \bar{x}+$ SD masuk golongan tinggi, $<\bar{x}-$ SD masuk golongan rendah, dan selebihnya masuk ke dalam golongan sedang, berikutnya bisa di carai skor tertinggi ( $\left.\mathrm{X}_{\text {maks }}\right)$ serta skor terendah $\left(\mathrm{X}_{\mathrm{min}}\right)$ pada kelas eksperimen maupun kelas kontrol. Kemudian dicari ukuran tendensi sentralnya yang meliputi rataan $(\overline{\mathrm{X}})$, median $\left(\mathrm{M}_{\mathrm{e}}\right)$, modus $\left(\mathrm{M}_{\mathrm{o}}\right)$, dan ukuran dispersi meliputi jangkauan (R) dan simpangan baku (s) yang dapat dirangkum dalam Tabel 1 berikut ini:

Tabel 1. Deskripsi Data Skor Minat Belajar Peserta Didik Kelas Eksperimen dan Kelas

\begin{tabular}{cccccccc} 
& \multicolumn{1}{c}{ Kontrol } \\
Kelompok & $\mathbf{X}_{\text {maks }}$ & $\mathbf{X}_{\text {min }}$ & \multicolumn{3}{c}{ Ukuran Tendensi Sentral } & \multicolumn{3}{c}{ Ukuran } \\
& & & $\overline{\mathbf{X}}$ & $\mathbf{M}_{\mathbf{0}}$ & $\mathbf{M}$ & $\mathbf{R}$ & $\mathbf{S}$ \\
Ekspersi & \\
Kontrol & 92 & 65 & 77 & $70,80,85$ & 75,5 & 27 & 7,283 \\
& 85 & 67 & 76,08 & 72 & 76 & 18 & 4,778 \\
\hline
\end{tabular}

Berdasarkan Tabel 1, untuk kelas eksperimen diperoleh nilai rataannya 77 dan simpangan baku 7,283, untuk skor $\geq 84,283$ dikategorikan tinggi, $69,717 \leq$ skor $<84,283$ dikriteriakan sedang dan skor $<69,717$ dikriteriakan rendah. Kelas kontrol dicapai nilai ratarata 76,08 dan simpangan baku 4,778, untuk skor skor $\geq 80,858$ dikategorikan tinggi, $71,302 \leq$ skor $<80,858$ dikategorikan sedang dan skor $<71,302$ dikategorikan rendah. Jadi, bisa ditarik kesimpulan bahwa minat belajar peserta didik kelas eksperimen lebih baik dibanding kelas kontrol.

Berdasarkan data yang sudah diperoleh, banyak peserta didik yang tergolong kedalam kriteria minat belajar tinggi, sedang dan rendah untuk kelas eksperimen serta kontrol bisa di lihat pada Tabel 2 berikut.

Tabel 2. Sebaran Berdasarkan Strategi Pembelajaran Ditinjau dari Minat Belajar

\begin{tabular}{ccccc}
\hline Strategi & MinatBelajar & \multicolumn{2}{c}{ Jumlah } \\
& Tinggi & Sedang & Rendah & 26 \\
Index Card Match (Eksperimen) & 6 & 17 & 3 & 25 \\
Konvensional (Kontrol) & 6 & 14 & 5 & 8 \\
Jumlah & 12 & 31 & 8 \\
\hline
\end{tabular}

Berdasarkan Tabel 2, jumlah peserta didik kelas eksperimen lebih banyak dibanding kelas kontrol yaitu 26 peserta didik untuk kelas eksperimen dan 25 peserta didik untuk kelas kontrol. Pada kelas eksperimen, peserta 
didik dengan minat belajar tinggi berjumlah 6 orang, peserta didik dengan minat belajar sedang berjumlah 17 orang, dan peserta didik dengan minat belajar rendah berjumlah 3 orang. Sedangkan pada kelas kontrol, peserta didik peserta didik dengan minat belajar tinggi berjumlah 6 orang, peserta didik dengan minat belajar sedang berjumlah 14 orang, dan peserta didik dengan minat belajar rendah berjumlah 5 orang. Berdasarkan data tersebut, dapat disimpulkan bahwa dalam penelitian ini jumlah peserta didik yang mempunyai minat belajar tinggi pada kelas eksperimen dan kelas kontrol mempunyai jumlah yang sama.

Data tentang kemampuan pemahaman relasional matematis peserta didik pada materi relasi dserta fungsi yang telah dicapai, berikutnya bisa di cari nilai tertinggi ( $\mathrm{X}_{\text {maks }}$ ) dan nilai terendah $\left(\mathrm{X}_{\min }\right)$ untuk kelas eksperimen meskipun kelas kontrol. Setelah itu dicari tolak ukur tendensi sentral yang mencakup rata-rata $(\bar{X})$, median $\left(\mathrm{M}_{\mathrm{e}}\right)$, modus $\left(\mathrm{M}_{\mathrm{o}}\right)$, dan ukuran dispersi mencakup capaian (R) dan simpangan baku (s) yang bisa dirangkum pada Tabel 3 berikut ini.

Tabel 3. Deskripsi Data Skor Kemampuan Pemahaman Relasional Matematis Kelas

Eksperimen dan Kelas Kontrol

\begin{tabular}{cccccccc}
\hline \multirow{2}{*}{ Kelompok } & \multirow{2}{*}{$\mathbf{X}_{\text {maks }}$} & \multirow{2}{*}{$\mathbf{X}_{\min }$} & \multicolumn{2}{c}{ Ukuran Tendensi Sentral } & \multicolumn{2}{c}{ Ukuran Dispersi } \\
& & & $\boldsymbol{X}$ & $\mathbf{M}_{\mathbf{0}}$ & $\mathbf{M e}_{\mathbf{e}}$ & $\mathbf{R}$ & $\mathbf{S}$ \\
Eksperimen & 97 & 63 & 76,5 & 69 & 75 & 34 & 9,471 \\
Kontrol & 91 & 50 & 68,2 & 72 & 69 & 41 & 10,186 \\
\hline
\end{tabular}

Berdasarkan Tabel 3, untuk kelas eksperimen diperoleh nilai terbesar 97 dan nilai terkecil 63 dengan nilai rataannya 76,5 dan simpangan baku 9,471 . Sedangkan untuk kelas kontrol diperoleh nilai terbesar 91 dan nilai terkecil 50 dengan nilai rataannya 68,2 dan simpangan baku 10,186. Sehingga bisa ditarik kesimpulan bahwa peserta didik yang mendapat pembelajran dengan strategi pembelajaran Index Card Matchmempunyai kemampuan pemahaman relasional matematis yang lebih baik dibanding peserta didik yang mendapat pembelajaran dengan metode pembelajaran konvensional.

Tabel 4. Deskripsi Data Kemampuan Pemahaman Relasional Matematis Ditinjau dari Minat Belajar

\begin{tabular}{cccccccc}
\hline Kelompok & \multirow{2}{*}{$\mathbf{X}_{\text {maks }}$} & $\mathbf{X}_{\min }$ & $\bar{X}$ & Ukuran Tendensi Sentral & \multicolumn{3}{c}{ Ukuran Dispersi } \\
Tinggi & 97 & 72 & 81,75 & $\mathbf{M}_{\mathbf{o}}$ & $\mathbf{M}_{\mathbf{e}}$ & $\mathbf{R}$ & $\mathbf{S}$ \\
Sedang & 94 & 53 & 72,355 & $69,78,81,97$ & 79,5 & 25 & 8,874 \\
Rendah & 66 & 50 & 58,75 & 63 & 70 & 41 & 8,073 \\
\hline
\end{tabular}

Berdasarkan Tabel 4, kemampuan pemahaman relasional matematis peserta didik yang mempunyai minat belajar tinggi diperoleh nilai terbesar 97 dan nilai terkecil 72 dengan rerata 81,75 dan simpangan baku 8,874. Kemampuan pemahaman relasional matematis peserta didik yang mempunyai minat belajar sedang diperoleh nilai terbesar 94 dan nilai terkecil 53 dengan rerata 72,355 dan simpangan baku 8,073. Sedangkan kemampuan pemahaman relasional matematis peserta didik yang mempunyai minat belajar rendah diperoleh nilai terbesar 66 dan nilai terkecil 50 dengan rerata 58,75 dan simpangan baku 5,970. Dengan 
Desimal, 2 (3), 2019 - 207

Fitri Wulandari, Rosida Rakhmawati

demikian, dapat disimpulkan bahwa kemampuan pemahaman relasional matematis peserta didik yang mempunyai minat belajar tinggi lebih baik dari pada peserta didik yang mempunyai minat belajar sedang maupun rendah. Hasil perhitungan anava dua jalan sel tak sama disajikan pada table 5 sebagai berikut

Tabel 5. Rangkuman Analisis Variansi Dua Jalan Sel Tak Sama

\begin{tabular}{|c|c|c|c|c|c|}
\hline Sumber & JK & Dk & RK & $F_{\text {hit }}$ & $\mathbf{F}_{\text {Tabel }}$ \\
\hline Model Pembelajaran (A) & 518,082 & 1 & 518,082 & 9,751 & 4,01 \\
\hline Minat belajar (B) & 2911,958 & 2 & 1455,98 & 27,403 & 3,159 \\
\hline Interaksi (AB) & 3,069 & 2 & 1,535 & 0,029 & 3,159 \\
\hline Galat (G) & 2390,913 & 45 & 53,131 & - & - \\
\hline Total (T) & 5824,022 & 50 & - & - & - \\
\hline
\end{tabular}

Berdasarkan hasil analisis variansi pada Tabel 5 rangkuman analisis variasni dua jalan sel tak sama, tampak bahwa :

1) Model Pembelajaran

Pada efek utama A (model pembelajaran), harga statistik uji $\mathrm{F}_{\mathrm{a}}=$ 9,751 dan $\mathrm{F}_{\text {Tabel }}=4,01$. Sedangkan $\mathrm{DK}=$ $\left\{F \mid F>F_{\text {hitung }}=4,01\right\}$ sehingga $F_{a} \in D K$. Jadi $\mathrm{H}_{0 \mathrm{~A}}$ ditolak, maka terdapat perbedaan kemampuan pemahaman relasional matematis antara peserta didik yang memperoleh pembelajaran dengan strategi pembelajaran Index Card Matchdengan metode pembelajaran konvensional.

2) Minat Belajar

Pada efek B (minat belajar), harga statistik uji $\mathrm{F}_{\mathrm{b}}=27,403$ dan $\mathrm{F}_{\text {Tabel }}=$ 3,159. Sedangkan $\mathrm{DK}=\{\mathrm{F} \mid \mathrm{F}>$ Fhitung $=$ $3,159\}$ sehingga $\mathrm{F}_{b} \in \mathrm{DK}$. Jadi $\mathrm{H}_{0 \mathrm{~B}}$ ditolak, maka terdapat perbedaan kemampuan pemahaman relasional matematis peserta didik yang mempunyai minat belajar tinggi, minat belajar sedang, maupun minat belajar rendah.

3) Interaksi

Pada interaksi efek AB (model pembelajaran dan minat belajar), harga statistik uji $\mathrm{F}_{\mathrm{ab}}=0,029$ dan $\mathrm{F}_{\text {Tabel }}=$ 3,159. Sedangkan $D K=\left\{F \mid F>F_{\text {hitung }}=\right.$ 3,159\} sehingga $\mathrm{F}_{\mathrm{ab}} \in \mathrm{DK}$. Jadi/ $\mathrm{H}_{0 \mathrm{AB}}$ diterima, maka Tidak terdapat interaksi antara model pembelajaran dan tingkat minat belajar peserta didik terhadap kemampuan pemahaman relasional matematis peserta didik.

\section{a. Uji Komparasi Ganda (Scheffe')}

Berdasarkan pengujian hipotesis, dari ketiga hipotesis terdapat dua hipotesis yang ditolak yaitu $\mathrm{H}_{0 A}$ dan $\mathrm{H}_{0 \mathrm{~B}}$, sedangkan $\mathrm{H}_{0 \mathrm{AB}}$ diterima. Oleh karena itu perlu dilakukan uji komparasi ganda untuk setiap hipotesis yang ditolak.

Tabel 6. Rataan Marginal

\begin{tabular}{lllll}
\hline \multirow{2}{*}{ Model Pembelajaran } & \multicolumn{2}{c}{ Minat Belajar Matematika } & \multirow{2}{*}{ Rataan Marginal } \\
& Tinggi & Sedang & Rendah & \\
Index Card Match & 85,333 & 75,588 & 64 & 76,5 \\
Konvensional & 78,167 & 68,429 & 55,6 & 68,2 \\
Rataan Marginal & 81,75 & 72,355 & 58,8 & \\
\hline
\end{tabular}


Dari Tabel 6, tampak bahwa rata-rata marginal untuk strategi pembelajaran Index Card Match adalah 76,5 sedangkan untuk metode pembelajaran konvensional adalah 68,2. Perhatikan bahwa $\mathrm{H}_{0 \mathrm{~A}}$, ini berarti terdapat perbedaan kemampuan pemahaman relasional matematis antara peserta didik yang memperoleh pembelajaran dengan strategi pembelajaran Index Card Match dengan peserta didik yang memperoleh pembelajaran dengan metode pembelajaran konvensional. Oleh karena itu, untuk antar baris tidak perlu dilakukan uji komparasi ganda pasca anava, cukup dengan melihat rataan marginalnya saja. Dari rataan marginalnya, menunjukan bahwa pada strategi pembelajaran Index Card Match lebih baik daripada metode pembelajaran konvensional. Dengan demikian dapat disimpulkan, bahwa kemampuan pemahaman relasional matematis peserta didik yang memperoleh pembelajaran dengan strategi pembelajaran Index Card Match lebih baik daripada peserta didik yang memperoleh pembelajaran dengan metode pembelajaran konvensional.

\section{SIMPULAN DAN SARAN}

Berdasarkan hasil dan pembahasan, dapat disimpulkan bahwa kemampuan pemahaman relasional matematis peserta didik yang mempunyai minat belajar tinggi lebih baik dibanding peserta didik yang mempunyai minat belajar sedang, kemampuan pemahaman relasional matematis peserta didik yang mempunyai minat belajar tinggi lebih baik daripada peserta didik yang mempunyai minat belajar rendah, dan kemampuan pemahaman relasional matematis peserta didik yang mempunyai minat belajar sedang lebih baik daripada peserta didik yang mempunyai minat belajar rendah. Dengan demikian terdapat perbedaan kemampuan pemahaman relasional matematis peserta didik yang mempunyai minat belajar tinggi, sedang dan rendah.
Berdasarkan kesimpulan tersebut, saran untuk peneliti selanjutnya adalah agar dapat mencoba meneliti dengan jangkauan yang lebih luas yaitu dengan menggunakan berbagai macam strategi pembelajaran terhadap kemampuan pemahaman relasioanal peserta didik

\section{DAFTAR PUSTAKA}

Arrafat, Y. (2014). Pengaruh Penerapan Strategi Pembelajaran Aktif Tipe Index Card Match Terhadap Pemahaman Konsep Matematis Siswa Kelas VII SMPN 17 Padang. Jurnal Wisuda Ke 48 Mahasiswa Prodi Pendidikan Matematika, 1(1).

Atikasari, G., \& Woro Kurniasih, A. (2015). Keefektifan Model Pembelajaran Kooperatif Dengan Strategi TTW Berbantuan Geogebra Terhadap Kemampuan Berfikir Kreatif Matematis Siswa Kelas VII Materi Segitiga. Unnes Journal of Mathematics Education, 4(1), 86-94.

Darhim, R. (2013). Pengaruh Strategi Pembelajaran Aktif Tipe Index Card Match Terhadap Kemampuan Pemahaman Instrumental dan Relasional pada Siswa SMP. Jurnal Online Pendidikan Matematika Kontemporer, 1(1), 7-13.

Fauzi, K. (2017). Cooperative Learning Index Card Match Model To Improve The Result Of Qur'an Hadith Learning. Mudarissa, 9(1), 53-73.

Haryanto. (2011). PengaruhStrategi Pembelajaran Aktif Card Sort Dan Index Card Match Terhadap Prestasi Belajar Getaran Dan Gelombang. $J P 2 F, 2(2)$.

Hasanah, U. (2016). Penerapan Strategi Pembelajaran Mind Mapping Untuk Meningkatkan Hasil Belajar Peserta Didik Pada Mata Pelajaran Fiqih Kelas VII A MTS Nurul Islam Air Bakoman Kabupaten Tanggamus. AlIdarah: Jurnal Kependidikan Islam, 6(2), 41-60.

Lusia. (2013). Penerapan Strategi Index 
Desimal, 2 (3), 2019 - 209

Fitri Wulandari, Rosida Rakhmawati

Card Match Untuk Meningkatkan Aktivitas Dan Hasil Belajar Matematika. Jurnal Pedagogi, 1(7).

Rambe, R. N. K. (2018). Penerapan Strategi Index Card Match Untuk Meningkatan Hasil Belajar Siswa Pada Mata Pelajaran Bahasa Indonesia. Jurnal Tarbiyah, 25(1), 93-124.

Saleh, M. (2013). Strategi Pembelajaran Fiqh Dengan Problem Based Learning. Jurnal Ilmiah DIDAKTIKA,
XIV(1), 190-220.

Surur, M., \& Urfi, R. N. U. (2017). Penerapan Model PBL Menggunakan Index Card Match Untuk Meningkatkan Aktivitas Dan Hasil Belajar Siswa Kelas X. Jurnal Pendidikan Edutaa, 4(2), 11-18.

Uswatusolihah, U. (2015). Membangun Pemahaman Relasional Melalui Komunikasi Interpersonal. Komunika, 7(2). 